\title{
Cost Analysis of Battery-powered Electric Vehicles in Macau
}

\section{Tze Wood Ching}

\author{
Department of Electromechanical Engineering, University of Macau, twching@ieee.org
}

\begin{abstract}
The development of electric vehicles (EVS) has advanced rapidly over the past decades. Researchers and engineers have concentrated on the improvement of EV performance through the advances in batteries, motors, converters, controllers and relevant auxiliaries, with great successes. Now, it comes to the stage of commercialization. It is important to understand various cost issues and the business models relating to EV application. This paper aims to discuss the life cycle cost (LCC) of both EV and internal combustion engine (ICE) vehicles in Macau. Viability of EVs will be assessed by comparing the LCCS of a Mitsubishi i-MiEV, and its comparable ICE counterpart " $i$ "; the fuel cost and $\mathrm{CO}_{2}$ emission reduction of an $E V$ will also be evaluated.
\end{abstract}

\section{Keywords}

electric vehicles, life cycle cost, vehicle performance, carbon dioxide emission, viability

\section{INTRODUCTION}

With the growing concerns on price fluctuation, depletion of petroleum resources, global warming, environmental and health, there is fast growing interest in electric vehicles (EVs) in Macau and also a pressing need for researchers and power utilities to develop various infrastructures for EVs and strategies for adapting EVs. Being a city with small geographical size $\left(29.5 \mathrm{~km}^{2}\right)$ limiting the travel range of vehicles, Macau has great potential for EV implementation [Ching, 2010; Ching, 2011; Ching and Lai, 2012].

With an urbanized city and limited land space, Macau has been faced with problems of road congestion and rapid growth in car population. Air pollution is also another important concern. EVs provide low emission urban transportation. Even taking into account the emissions from power plants needed to fuel the vehicles, the use of EVs can reduce carbon dioxide $\left(\mathrm{CO}_{2}\right)$ emissions significantly. From the energy aspect, EVs are efficient and environmentally friendly [Chan, 2004; Chan and Wong, 2004; Chan, 2007]. Thus, EVs are promising green vehicles that can reduce both energy consumptions and $\mathrm{CO}_{2}$ emissions [Wong et al., 2010; Ching, 2011].

\section{EVS IN MACAU}

In November 2010, the Macau Government announced to promote "Green Vehicles" by offering tax incentives in acquisition of "energy efficient vehicles" [Macao SAR, 2010]. During past two years, several

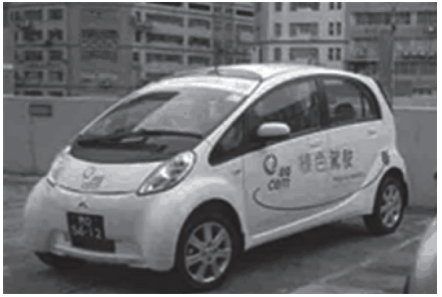

(a)

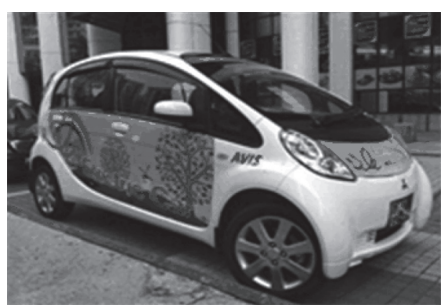

(c)

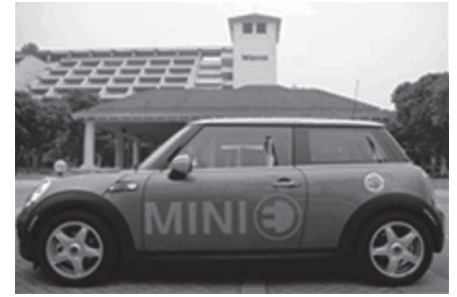

(b)

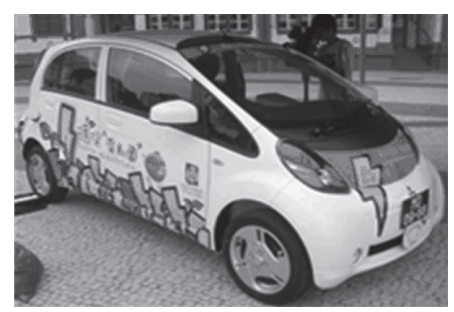

(d)

Fig. 1 BEVs in Macau: (a) Power Company; (b) For public trial; (c) Car renting company; (d) Macau Government 
public test rides and demonstrations of electric bikes, scooters, mini/mid-size sedans and buses were conducted by manufacturers from Europe, Japan, Taiwan and China, some of them are shown in Figure 1.

The Macau Government approved in February 2012 to promote "Green Vehicles" by offering $50 \%$ tax reduction (with a limit of MOP 60,$000 ; 1 \mathrm{USD} \approx$ MOP8) in acquisition of energy efficient vehicles [Macao SAR, 2012]. Vehicle import taxes are shown in Table 1. Three battery-powered EVs (BEVs) were imported to Macau, the first by the power company, the second by a car renting company (both in April 2010 and had been running in real-world for more than 32 months); the third was bought by Macau Government in September 2011.

Table 1 Motor vehicle tax (1 USD $\approx$ MOP 8 )

\begin{tabular}{|c|c|}
\hline Vehicle Price (MOP) & Tax \\
\hline $0-100,000$ & 0 \\
\hline $100,000-200,000$ & $40 \%$ \\
\hline $200,000-300,000$ & $65 \%$ \\
\hline $300,000-500,000$ & $70 \%$ \\
\hline$>500,000$ & 0 \\
\hline
\end{tabular}

A project was launched to investigate the performance of EV, specifically for sub-tropical environment of Macau. Due to the high temperature and humidity, performance of EVs operated in Macau was yet to be understood. Previous experimental studies conducted in the US, Europe or Japan might not reflect the actual local real-road driving conditions. The EV performance study was a collaboration work between the University of Macau (UM) and a local electric power company, Companhia de Electricidade de Macau (CEM), aimed to understand issues relating to $\mathrm{EV}$ adoption [CEM, 2010].

A BEV in Fig. 1(a) equipped with a $16 \mathrm{kWh}$ battery [Mitsubishi, 2010] was used for experiments and evaluation, while an internal combustion engine (ICE) powered counterpart " $i$ " [Mitsubishi, 2009], was used as baseline. The maximum output of the sample $\mathrm{BEV}$ is $47 \mathrm{~kW}$ which is the same as " $\mathrm{i}$ " with a turbo ICE [Wada, 2010]. Recently, a new model of i-MiEV with a smaller battery of $10.5 \mathrm{kWh}$ (cruising distance reduced from $160 \mathrm{~km}$ to $120 \mathrm{~km}$ ) was launched [Mitsubishi, 2012], their initial purchasing prices together with import taxes (listed in Table 1) were tabulated in Table 2.

The previous experimental works [Ching, 2011] aimed at the road testing of EVs and evaluation of fuel costs and $\mathrm{CO}_{2}$ reductions when EVs are adopted in Macau area. Road test also revealed that a fuel cost saving of more than $70.4 \%$ could be achieved when both the EV and ICEV were tested under same routes, with results summarized in Tables 3 to Table 4.

\section{LIFE CYCLE COST ANALYSIS}

It is the most expensive to pay upfront for acquiring an EV, but not the costs for operating and maintaining! To investigate the various costs and the future business models relating to EV application, it was proposed to evaluate the present value of life cycle cost (LCC) [Wong et al., 2010; Ching and Lai, 2012] of an

Table 2 Price of vehicles

\begin{tabular}{|c|c|c|c|}
\hline & JPY & MOP & MOP (Taxed) \\
\hline “i” (ICEV) & $1,405,714$ & 137,749 & 152,829 \\
\hline i-MiEV $(16 \mathrm{kWh})$ & $3,619,048$ & 354,639 & 437,887 \\
\hline i-MiEV $(10.5 \mathrm{kWh})$ & $2,476,191$ & 242,648 & 276,508 \\
\hline
\end{tabular}

Table 3 Fuel cost and consumption

\begin{tabular}{|c|c|c|}
\hline & EV $(\mathrm{MOP})$ & ICE (MOP) \\
\hline Fuel price & 1.223 per $\mathrm{kWh}$ & 9.85 per Liter \\
\hline Fuel consumption & $0.1469 \mathrm{kWh}$ per km & 0.0616 Liter per $\mathrm{km}$ \\
\hline Fuel cost per distance travelled & 0.1797 per km $(29.6 \%)$ & 0.6068 per $\mathrm{km}(100 \%)$ \\
\hline
\end{tabular}

Table 4 Comparison of $\mathrm{CO}_{2}$ emissions

\begin{tabular}{|c|c|c|}
\hline Electricity generation & EV & ICE \\
\hline $383.16 \mathrm{~g} / \mathrm{kWh}$ & $56.278 \mathrm{~g} / \mathrm{km}(48.1 \%)$ & $117 \mathrm{~g} / \mathrm{km}(100 \%)$ \\
\hline
\end{tabular}


Table 5 Operating and maintenance costs

\begin{tabular}{|c|c|c|}
\hline & EV (MOP) & ICE (MOP) \\
\hline Engine oil & - & $2,000($ every $5,000 \mathrm{~km})$ \\
\hline Tires & $2,000($ every $36,000 \mathrm{~km})$ & $2,000($ every $36,000 \mathrm{~km})$ \\
\hline Routine maintenance & $1,000($ every $12,000 \mathrm{~km}$, after $60,000 \mathrm{~km})$ & $5,000($ every $12,000 \mathrm{~km}$, after $60,000 \mathrm{~km})$ \\
\hline Battery $(12 \mathrm{~V})$ & $500($ every $36,000 \mathrm{~km})$ & $500($ every $36,000 \mathrm{~km})$ \\
\hline Vehicle circulation tax & - & 850 per year \\
\hline Fuel & $0.1469 \mathrm{kWh}$ per km & 0.0616 Liter per km \\
\hline
\end{tabular}

EV and compare with an ICE vehicles.

\subsection{Upfront costs and taxes}

In Macau, the motor vehicle tax (Table 1) was already included in the vehicle purchase price listed by a dealer (Table 2), but the owners are required to pay the vehicle circulation tax annually (Table 5), which will be waived for EVs in Macau.

\subsection{Operating and maintenance $(O \& M)$ costs}

Acquisition cost of EVs is high. However, EVs are much more efficient than ICE vehicles [Ching, 2011], their o\&m costs are also much lower. Various maintenance and operating costs for ICEV and EV are compared in Table 5.

\subsubsection{Forecast of gasoline price}

Historical quarterly price of gasoline from Q4/2008 to Q4/2011 [DESC, 2012] was used to forecast the future gasoline price from 2012 to 2021, using equations (1)(3) below, as $y$ is the forecast for period $t$ :

$y_{t}=a+b t$

where

$b=\frac{n \Sigma t y-\Sigma t \Sigma y}{n \Sigma t^{2}-(\Sigma t)^{2}}$

and

$a=\frac{\Sigma y-b \Sigma t}{n}$

Similarly, historical yearly electricity prices [DESC, 2012] from 2007 to 2011 were used to forecast the future electricity price from 2012 to 2021, using the same decomposition approach. Parameters a, b and forecasting accuracy were to be further investigated and analyzed in the future. Results of forecasted prices of gasoline and electricity are shown graphically in Figure 2 and Figure 3 respectively.

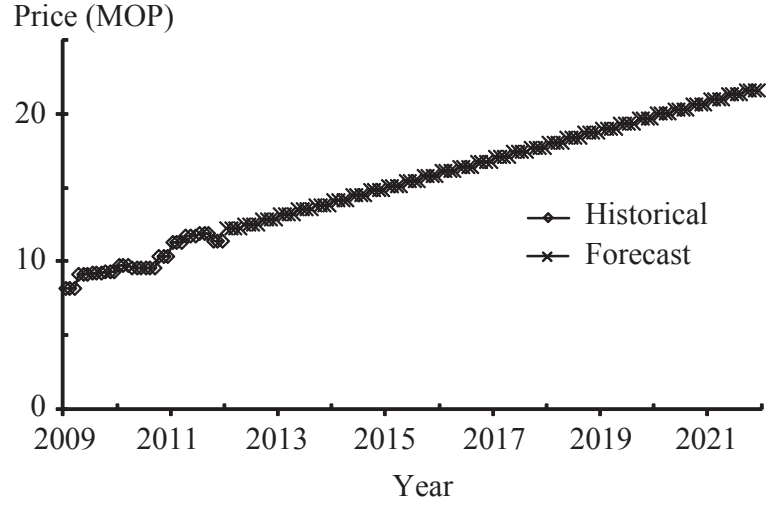

Fig. 2 Prices of gasoline in Macau

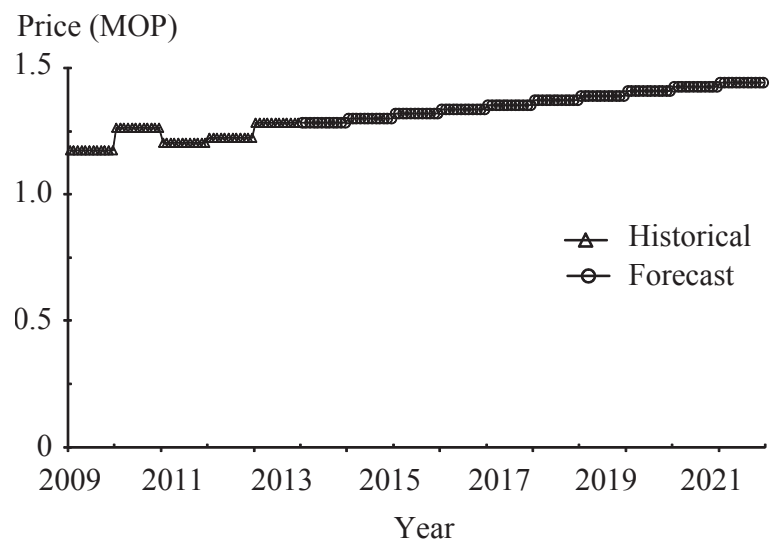

Fig. 3 Prices of electricity in Macau

\subsubsection{Present value of $0 \& m$ costs}

Expenditures for o\&m are to be happened in the future, for example, the monthly fuel consumption costs are to be settled monthly. When comparing the LCCs, the present values of future expenditures are evaluated using equation (4):

$P=\frac{F}{(1+i)^{n}}$

where:

$P=$ present value of expenditure 
$F=$ future expenditure

$i=$ interest rate $(2.81 \%$ in 2011$)$

$n=$ interest compounding period

\subsection{Costs to consumer}

LCCs are the summation of all costs mention in sections 3.1 to section 3.2 (upfront cost listed in Table 2 and o \& $m$ costs tabulated in Table 5), over the lifetime of the vehicles. By assuming both the ICEV and EVs are to be used in Macau, and assuming a monthly driving range of $1000 \mathrm{~km}$, all costs listed in Tables 1-2 incurred during the ten years of operation were calculated and listed in Table 6 and plotted in Figure 4.

From Table 6, after 120 months of operation, the total costs of an ICEV will be MOP340,062 while it is higher than MOP308,593, the total costs of an EV equipped with $10.5 \mathrm{kWh}$ battery. From Figure 4, the break-even time for these two vehicles was estimated to be at the 100th month of operation, i.e. April 2020. Since options for battery maintenance and replacement are not available in Macau, additional costs may

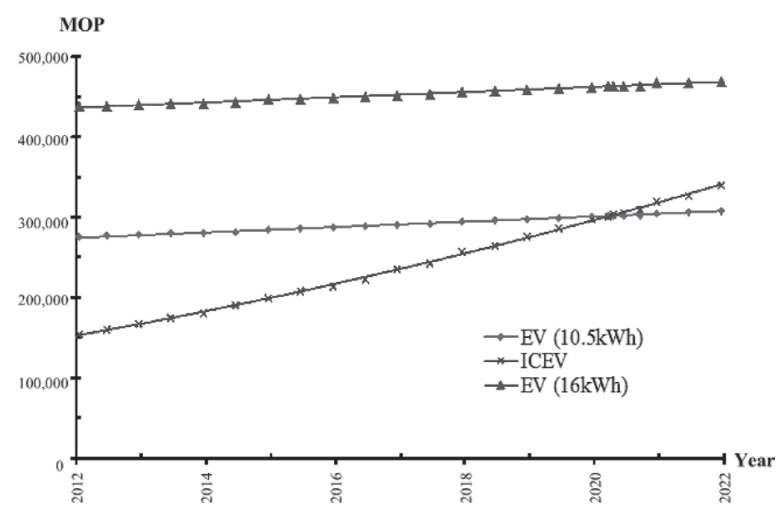

Fig. 4 Present values of LCC for 3 vehicles incur in the future.

\section{CONCLUSION}

A cost model has been developed to calculate various costs to be incurred during the ten years of operation of two BEVs, and a comparable ICEV “i” was used as a benchmark. Their acquisition cost, taxes, Government Incentives, the present values of their future operation and all external costs are estimated and compared. Fuel consumption data and costs obtained in previous experimental studies were utilized in this exercise and their future prices were forecasted using linear decomposition approach.

Results obtained from this LCC study are the cost savings from monthly fuel consumption and various maintenance expenditures will compensate the high upfront initial cost of the EV being studied, the breakeven time was estimated to be 100 months in Macau's context. Furthermore, $\mathrm{CO}_{2}$ displacement can be reduced (as compared in Table 4) by $6072 \mathrm{~kg}$ during that 100 months period with monthly driving range of $1000 \mathrm{~km}$. Additional reduction could be achieved when more renewable energy sources or non-coal electricity was used for the generation of electricity. EVs are clean due to their zero local emissions and low global emissions. They are also green due to their environmental friendliness, since electricity can be generated by renewable energy sources to achieve sustainable mobility and zero emissions [UBC, 2010].

\section{Acknowledgements}

This paper was supported by the Research Council of the University of Macau under MYRG041(Y1-L1)FST12-TWC and CG086- FST2012-CTW.

The author gratefully acknowledge Mr. K. Lai \& L.

Table 6 Present values of LCCs (MOP)

\begin{tabular}{|c|c|c|c|}
\hline & “i” (ICEV) & i-MiEV $(16 \mathrm{kWh})$ & i-MiEV $(10.5 \mathrm{kWh})$ \\
\hline Purchase & 152,829 & 437,887 & 276,508 \\
\hline 12th month & 166,745 & 440,115 & 278,737 \\
\hline 24th month & 180,965 & 442,311 & 280,933 \\
\hline 36th month & 199,621 & 446,774 & 285,396 \\
\hline 48th month & 214,361 & 448,907 & 287,529 \\
\hline 60th month & 235,429 & 451,878 & 290,499 \\
\hline 72th month & 256,928 & 456,906 & 295,527 \\
\hline 84th month & 276,395 & 459,767 & 301,195 \\
\hline 96th month & 297,522 & 462,574 & 305,891 \\
\hline 108th month & 318,995 & 467,270 & 308,593 \\
\hline 120th month & 340,062 & 469,972 & \\
\hline
\end{tabular}


Iong of UM and Mr. P. Diniz, of CEM for their supports and assistance on this study.

\section{References}

CEM, EV study in Macau, http://www.cem- macau. com/CEM-signs-protocol-with-University, 2010.

Chan, C. C., The state of the art of electric vehicles, Journal of Asian Electric Vehicles, Vol. 2, No. 2, 579-600, 2004.

Chan, C. C., and Y. S. Wong, Electric vehicles charge forward, IEEE Power \& Energy Magazine, 25-33, 2004.

Chan, C. C., The state of the art of electric, hybrid, and fuel cell vehicles, Proceedings of the IEEE, Vol. 95, No. 4, 704-708, 2007.

Ching, T. W., Electric vehicle charging station in Macau, World Electric Vehicle Journal, Vol. 4, 677 684, 2010.

Ching, T. W., Road testing of electric vehicle in Macau, Journal of Asian Electric Vehicles, Vol. 9, No. 2, 1491-1495, 2011.

Ching, T. W., and K. Lai, Life cycle cost analysis of battery-powered electric vehicles in Macau, Proceedings of the International Conference on Electrical Engineering, 1340-1344, 2012.

DESC, Statistic (Balance of energy), http:// www. dsec.gov.mo/Statistic.aspx, 2012

Macao SAR, Policy address for the fiscal year 2010 , http://portal.gov.mo/web/guest/info_ detail?infoid=15947, 2010.

Macao SAR, Macau Law No. 1-2012, http:// http://images.io.gov.mo/bo/i/2012/06/lei-1-2012.pdf, 2012.

Mitsubishi, Features of T, http:// www.mitsubishimotors.co.jp/i/grade/gra_01.html, 2009.

Mitsubishi, Features of G, http:// www.mitsubishimotors.co.jp/i-miev/grade/gra_01.html, 2010.

Mitsubishi, Features of M, http:// www.mitsubishimotors.co.jp/i-miev/grade/gra_02.html, 2012.

UBC, UBC electric car first to beetle across Canada, http://www.publicaffairs.ubc.ca/2010/ 08/30/ubcelectric-car-first-to-beetle-across-canada, 2010.

Wong, Y. S., W. Lu, Z. Wang, and Y. Liu, Life cycle cost analysis of different vehicle technologies in Singapore, The 25th World Battery, Hybrid and Fuel Cell Electric Vehicle Symposium \& Exhibition, CD-Rom, 2010.

Wada, K., Further Evolution Towards a new generation of electric vehicles i-MiEV", Journal of Asian Electric Vehicles, Vol. 8, No. 2, 1405-1408, 2010.

(Received November 29, 2012; accepted December 20, 2012) 